\title{
Two new species of Hypoptopomatinae from the rio Paraíba do Sul basin, with comments on the monophyly of Parotocinclus and the Otothyrini (Siluriformes: Loricariidae)
}

\author{
Marco F. W. Gauger and Paulo Andreas Buckup
}

Two new species of loricariid catfishes, Parotocinclus bidentatus and P. muriaensis, are described from the rio Paraíba do Sul basin. They possess accessory unicuspid teeth located internally to the series of bicuspid teeth in premaxillary and dentary bones. According to a parsimony analysis of phylogenetic relationships among the Hypoptopomatinae, the new taxa are members of the genus Parotocinclus, even though they lack a fully developed adipose fin. They differ from most species of Parotocinclus because they have accessory teeth. Within the Hypoptopomatinae, accessory teeth are also found only in $P$. collinsae and members of the genera Eurycheilichtys, Epactionotus and Niobichthys.

Duas novas espécies de cascudinhos loricariídeos, Parotocinclus bidentatus e P. muriaensis, são descritas da bacia do Rio Paraíba do Sul. Elas possuem dentes unicúspides localizados internamente à série de dentes bicúspides dos ossos pré-maxilar e dentário. De acordo com uma análise de parcimônia das relações filogenéticas entre os Hypoptopomatinae, as novas espécies pertencem ao gênero Parotocinclus, apesar de não possuírem a nadadeira adiposa plenamente desenvolvida. Elas diferem da maioria das espécies de Parotocinclus pela presença de dentes acessórios. Entre os Hypoptopomatinae dentes acessórios ocorrem apenas em P. collinsae e membros dos gêneros Eurycheilichthys, Epactionotus e Niobichthys.

Keywords: Neotropical Region, Cascudinhos, Systematics, Taxonomy, Freshwater fish.

\section{Introduction}

Two new species of Hypoptopomatinae were discovered during an inventory of the subfamily in the ichthyological collection of the Museu Nacional (MNRJ), Rio de Janeiro, Brazil. The specimens stood out due to the presence of accessory unicuspid teeth behind the series of bicuspid teeth in premaxillary and dentary bones. This character is shared only with Parotocinclus collinsae Schmidt \& Ferraris, 1985, and the genera Epactionotus, Eurycheilichthys, and Niobichthys (Schmidt \& Ferraris, 1985; Reis \& Schaefer, 1992; Reis \& Schaefer, 1998; Schaefer \& Provenzano, 1998).

The new species are members of the Otothyrini (Schaefer, 1991) according to a preliminary cladistic analysis using the data matrix of Schaefer (1998). However, the morphology of the new species prompted a re-examination of Schaefer's data. A new analysis based on our expanded character set and numerous additional taxa shows that the new species are more closely related to the type species of Parotocinclus than to
Eurycheilichthys, Epactionotus, or Niobichthys. Here we describe the two species as provisional members of the genus Parotocinclus and present a brief discussion of the phylogenetic hypothesis that supports such placement.

\section{Material and Methods}

Measurements and counts follow Boeseman (1968: 26-27) and Schaefer (1997: 9-11). Additionally, the width and length of the lips and the head width at the canal-bearing cheek plates were obtained. Morphometric data were measured using a digital caliper and were recorded to the nearest 0.1 $\mathrm{mm}$. Standard length (SL) and head length (HL) were used throughout as references. Tooth and fin-ray counts presented in the text are modal values.

Osteological preparations were made following Taylor \& Van Dyke (1985). The cleared and stained specimens (c\&s) were compared with the $c \&$ s specimens of Hypoptopomatinae available from MNRJ and other institutions. Institutional

Departamento de Vertebrados, Museu Nacional, Universidade Federal do Rio de Janeiro, 20940-040 Rio de Janeiro, RJ, Brazil. e-mails: marco-s@gmx.net,buckup@acd.ufrj.br 
abbreviations are used as listed in Leviton et al. (1985), except for CBF, which stands for Collección Boliviana de Fauna, Museo Nacional de Historia Natural, Bolivia.

The phylogenetic analysis was performed according to the principles of Hennig (1966) using the software PAUP version 4.0 beta 10 for Windows (Swofford, 2003). A matrix was prepared involving 31 taxa and 57 characters (see Appendix). The matrix included 45 characters previously used by Schaefer (1998), but with some modifications, and 11 new characters (see below). In addition to the two new species, the matrix included representatives of 15 genera studied by Schaefer (1998). Each genus was represented in our matrix by one species, except for Parotocinclus, which is represented by seven species. The use of seven representatives of Parotocinclus instead of a single composite taxon provides a test of group monophyly and a better representation of the morphological diversity exhibited by the group. Additionally, we included Corumbataia tocantinensis Britski, 1997, and seven undescribed taxa from central Brazil. The undescribed species from central Brazil are the subject of an ongoing study by M. R. Britto, P. A. Buckup, and R. E. Reis, and were included because they provide new insights into the phylogeny of the Hypoptopomatinae and affect the relationships of Parotocinclus. Neoplecostomus microps Steindachner, 1877, and a composite taxon representing the other subfamilies of Loricariidae were used as outgroups.

In the data matrix used in the phylogenetic analysis (see Appendix) characters 1 to 46 correspond to those of Schaefer (1998), except for the following differences:

Character 30: Pectoral skeleton arrector fossae closure. The character state originally described by Schafer (1998) as " $a r$ rector fossae partially enclosed by a ventral lamina of the coracoids which underlies the arrector ventralis muscles" is here subdivided into two states: state 30,1 designates those taxa where the opening is relatively ample, extending laterally halfway towards the base of the pectoral fin (Fig. 1); state 30,2 designates those taxa where the opening is restricted to a small area near the ventral midline (Fig. 2). The state originally coded as 30,2 by Schaefer (1998) is recoded here as state 30,3 .

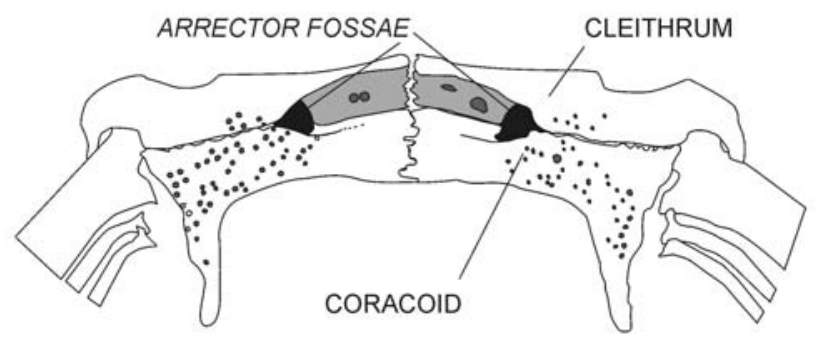

Fig. 1. Ventral view of pectoral girdle of Parotocinclus muriaensis, MNRJ 14753, c\&s, 27.3 mm SL. Gray= cleithral roof of arrector fossae.
Character 32: Truncation of the mid-dorsal lateral plate series. Schaefer (1998) coded species with nine or more middorsal plates as plesiomophic, and species with five or less plates as having a truncated lateral plate series. We found that species with a truncated series may occasionally have as many as eight plates, and therefore redefined the apomorphic stated to include eight or fewer plates.

Character 39: Enlarged snout odontodes. Character no longer ordered because species with enlarged odontodes on the antero-ventral margin of the snout have no enlarged odontodes on the rostrum.

In addition to the characters presented by Schaefer (1998), the following characters were added:

Character 47: Mesethmoid covered by prenasal plates (state 47,0 ). Mesethmoid exposed on the dorsal surface of head (state $47,1)$.

Character 48: Infraorbital canal enters the infraorbital series via the sphenotic (state 48,1). In Othothyris and Corumbataia the canal enters the infraorbital series via the pteroticsupracleithrum (state 48,2). This character corresponds to Schaefer (1991, character 48).

Character 49: Lateral ethmoid exposed on the surface of the head posterior to nostrils, with at least one series of odontodes (state 49,0). Lateral ethmoid not exposed on the dorsal surface of head (state 49,1).

Character 50: Supraoccipital without crests (state 50,0). Supraoccipital with longitudinal crests (state 50,1).

Character 51: Postanal ventral plates do not meet at the midline (state 51,0). Contact of one or more postanal ventral plates at the midline (state 51,1 ).

Character 52: Adipose-fin spine present and well developed (state 52,0). Adipose-fin spine represented by one to three

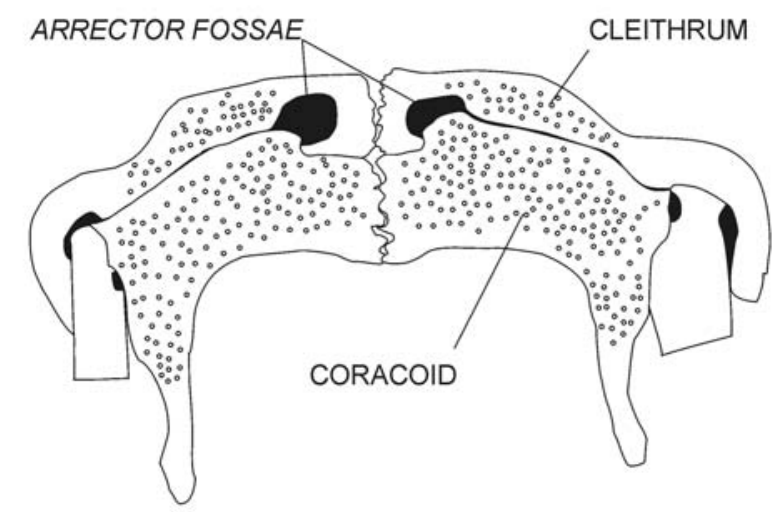

Fig. 2. Ventral view of pectoral girdle of Parotocinclus bidentatus, MNRJ 14217, c\&s, $32.5 \mathrm{~mm} \mathrm{SL}$. 
unpaired platelets at typical adipose-fin position (state 52,1). Neither adipose fin nor unpaired plates present at typical adipose-fin position (state 52,2) This character is unordered.

Character 53: Pectoral girdle not exposed ventrally, where it is covered by thick skin (state 53,0). Ventral surface of pectoral girdle only exposed laterally (state 53,1). Pectoral girdle completely exposed (state 53.2). This character is treated as unordered.

Character 54: Length of median rostral plate or plates smaller than its/their width (state 54,0). Length of median rostral plate greater than its width (state 54,1 ).

Character 55: Dermal plates of thorax and abdomen small and irregularly distributed (state 55,0). Plates of thorax and abdomen large $(55,1)$.

Character 56: Thorax and abdomen entirely covered with dermal plates (state 56,0). Thorax and abdomen with naked areas (state 56,1 ).

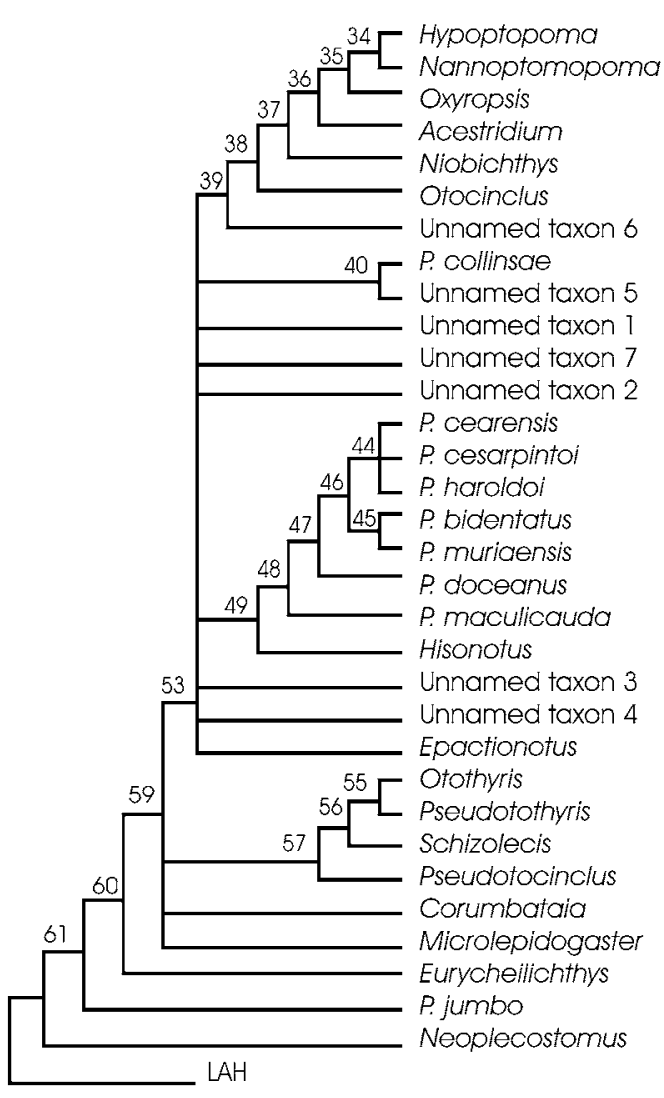

Fig. 3. Consensus cladogram of 153 most parsimonious hypotheses of Hypoptopomatinae relationships. See Comparative Material of a complete list of specimens representing each taxon. Numbers correspond to clades in Fig. 2. P. = Parotocinclus.
Character 57: Skin between lateral process of cleithrum and insertion of pectoral fin without slit of dermal pore (state 57,0). Dermal slit present between lateral process of cleithrum and insertion of pectoral fin (state 57,1). Character coded according to Reis \& Schaefer (1998, fig. 10).

\section{Results}

The parsimony analysis of the expanded data matrix of 57 characters produced 153 equally parsimonious trees ( 170 character-state transformations, consistency index $=0.42$,

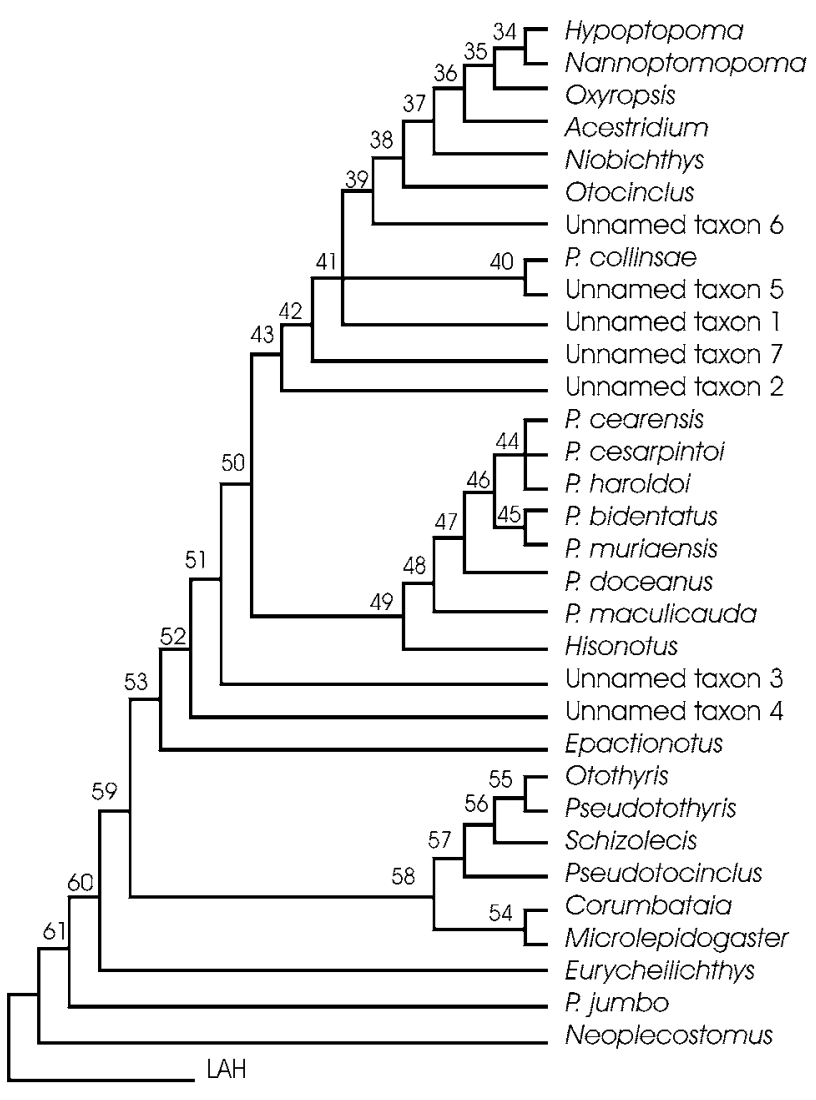

Fig. 4. Most parsimonious cladogram selected by successive weighting. Character-state changes optimized by accelerated transformation are as follows (unambiguous transformations are italicized). Clade 34: 9:1, 20:0, 22:1, 38:2,41:1. Clade 35: 2:1, 16:1, 33:0, 43:1. Clade 36: 21:1, 24:2, 28:1, 45:1, 47:1. Clade 37: 6:1, 10:0, 17:1, 24:1; 25:1, 27:2, 29:1, 33:2, 36:1, 42:1. Clade 38: 7:1, 13:1, 14:1, 18:0, 19:1, 20:1, 31:0, 38:1, 54:0. Clade 39:30:3, 37:0. Clade 40: 15:0. Clade 41: 49:1. Clade 42: 54:1. Clade 43: 3:0, 15:1. Clade 44: 31:0, 56:1. Clade 45: 44:1, 52:1. Clade 46: 55:0. Clade 47: 3:0. Clade 48: 32:0, 37:0, 52:1. Clade 49: 35:1. Clade 50: 31:1, 34:1. Clade 51: 55:1, 56:0. Clade 52: 27:0, 31:0, 32:1. Clade 53:39:2. Clade 54: 14:1. Clade 55: 8:1, 39:1. Clade 56:12:1, 23:1, 27:2, 42:1, 49:1, 57:0. Clade 57: 50:1. Clade 58: 11:1. Clade 59:3:1, 30:2, 53:2. Clade 60: 10:1, 31:1, 51:1, 52:2, 57:1. Clade 61: 5:1, 13:2, 18:1,27:1,30:1,37:1, 53:1, 56:1. 
retension index $=0.27$ ). In all cladograms, the Otothyrini is not monophyletic, and the consensus cladogram (Fig. 3) differs significantly from Schaefer's (1998) hypothesis of Hypoptopomatinae relationships. Despite the conflicts that produce a poorly resolved consensus cladogram, the two new species with accessory teeth form a monophyletic lineage in all cladograms. That lineage is a member of a wider monophyletic assemblage that includes most species of Parotocinclus, including its type species, P. maculicauda.

To illustrate the diagnostic characters that support our hypothesis of relationships we selected one of the most parsimonious cladograms by successively reweighting the characters based on maximum value of their rescale consistency indices and reanalysing the data. This procedure converged into two equally parsimonious cladograms which differ solely on whether or not the branch leading to the sister group of unnamed species 1 is collapsed (Fig. 4). The most parsimonious reconstruction indicates that the relationship between the new species with $P$. maculicauda and other species of Parotocinlus is supported by the following synapomorphies: (1) series of mid-dorsal plates continued along the median series, bearing more than eight plates (character 32), (2) fourth infraorbital not expanded ventrally (Schaefer, 1991, fig.10B; character 37), and (3) presence of azygous spinelets on the caudal peduncle that correspond to the adipose fin (charac- ter 52). The two new species are therefore described as members of Parotocinlus.

\section{Parotocinlus bidentatus, new species}

Fig. 5

Holotype. MNRJ 27962, 34.8 mm SL, rio Pirapetinga (left bank tributary of rio Paraíba do Sul), Município de Resende (22 $\left.28^{\prime} 08^{\prime \prime} \mathrm{S} 44^{\circ} 26^{\prime} 48^{\prime \prime} \mathrm{W}\right)$, Rio de Janeiro State, Brazil, G. W. A. Nunan, L. E. M. Cardoso, W. D. Bandeira, 28-30 May 1982. Paratypes. MNRJ 14217, 9, 17.7-34.5 mm SL, 1 c\&s 32.5 mm SL, AMNH 236543, 3, 26.4-30.8 mm SL, collected with the holotype; MNRJ 16011, 1, $28.9 \mathrm{~mm}$ SL, rio Calçado (right bank tributary of rio Paraíba do Sul), approx. $22^{\circ} 6^{\prime} \mathrm{S} 43^{\circ} 4^{\prime} \mathrm{W}$, near highway BR-393, Município de Três Rios, E. P. Caramaschi et al., 23 May 1989; MNRJ 17467, 1, 29.5 mm SL, rio Pirapetinga, Município de Resende, G. W. Nunan \& W. D. Bandeira, 18 Sep 1982; MNRJ 28225, 1, 34.3 mm SL, rio Barreiro de Baixo (tributary of rio Pirapetinga, Paraíba do Sul basin), 6 Oct 1978; MNRJ 28226, 2, 26.1-30.0 mm SL, same locality, G. W. Nunan \& W. D. Bandeira, 22 Aug 1982.

Diagnosis. Parotocinclus bidentatus can be distinguished from all other Hypoptopomatinae except Niobichthys, Epactionotus, Eurycheilichthys, Parotocinclus collinsae,

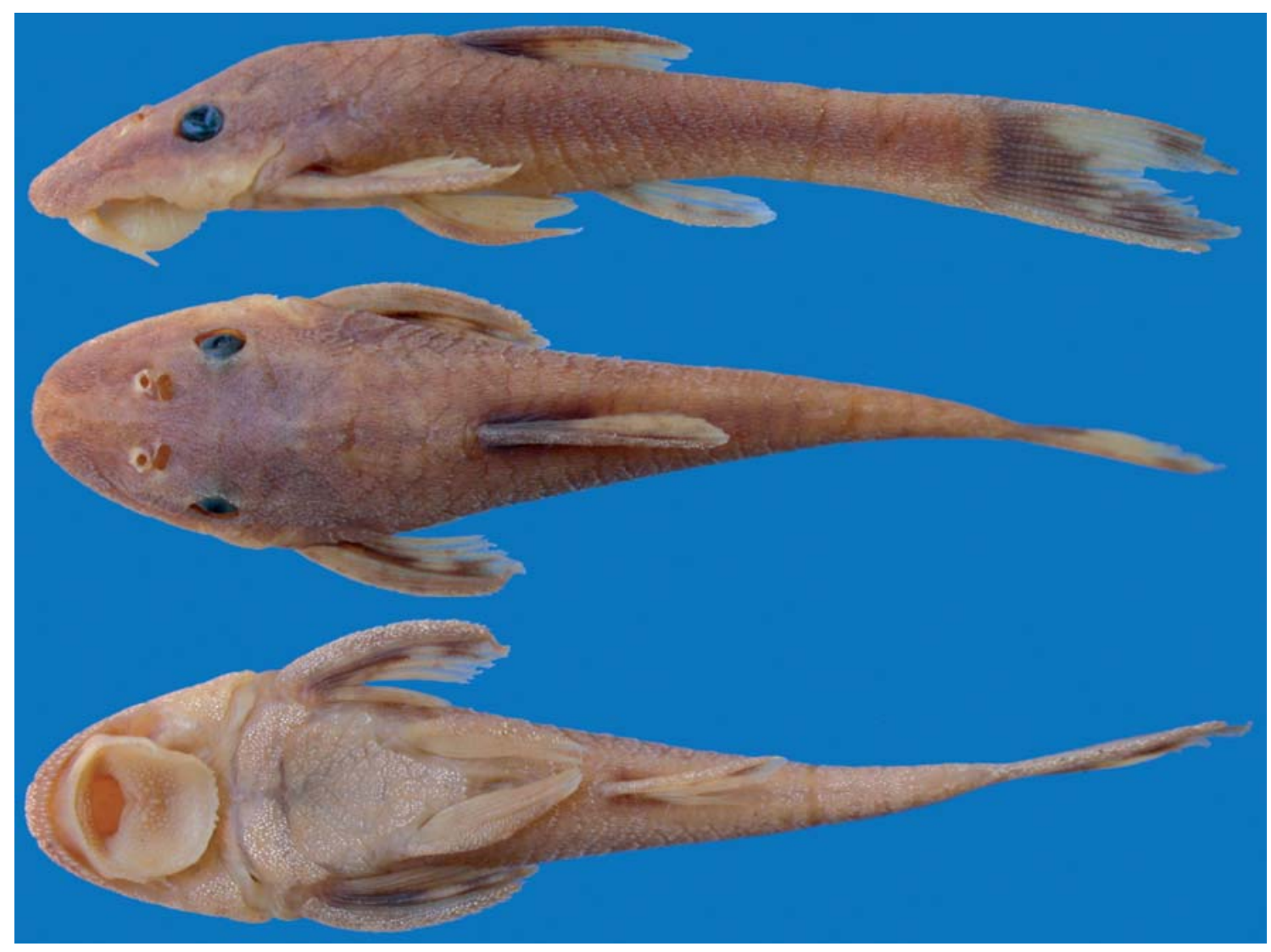

Fig. 5. Parotocinclus bidentatus, holotype MNRJ 27962, $34.8 \mathrm{~mm}$ SL. Brazil: Rio de Janeiro State: rio Pirapetinga (left bank tributary of rio Paraíba do Sul), Resende. 
Table 1. Morphometric and meristic data for Parotocinclus bidentatus. $\mathrm{Hol}=$ Holotype.

\begin{tabular}{|c|c|c|c|c|c|c|}
\hline & Hol & $\mathbf{N}$ & Low & High & Mean & SD \\
\hline Standard length $(\mathrm{mm})$ & 34.8 & 16 & 24.6 & 34.8 & 29.4 & 3.5 \\
\hline Head length (mm) & 12.6 & 16 & 9.2 & 12.6 & 10.6 & 1.0 \\
\hline \multicolumn{7}{|c|}{ Percent of Standard Length } \\
\hline Predorsal length & 46.3 & 16 & $43.2^{\circ}$ & 47.4 & 45.5 & 1.2 \\
\hline Head length & 36.3 & 16 & 33.8 & 38.5 & 36.3 & 1.3 \\
\hline Dorsal-fin spine length & 26.2 & 11 & 22.8 & 28.4 & 25.6 & 1.6 \\
\hline Dorsal-fin base length & 11.5 & 16 & 11.5 & 14.2 & 13.0 & 0.8 \\
\hline Trunk length & 11.5 & 16 & 11.5 & 16.3 & 13.9 & 1.1 \\
\hline Pectoral-fin length & 24.6 & 16 & 17.8 & 27.3 & 23.9 & 2.1 \\
\hline Abdominal length & 21.5 & 16 & 19.4 & 22.6 & 21.3 & 1.0 \\
\hline Caudal-peduncle length & 33.6 & 16 & 30.0 & 38.5 & 32.9 & 2.2 \\
\hline Caudal-peduncle depth & 12.2 & 16 & 9.8 & 14.3 & 12.9 & 1.2 \\
\hline \multicolumn{7}{|c|}{ Percent of Head Length } \\
\hline Head depth & 45.1 & 16 & 38.7 & 47.5 & 43.5 & 2.4 \\
\hline Snout length & 56.6 & 16 & 48.6 & 56.6 & 53.6 & 2.1 \\
\hline Horizontal eye diameter & 16.2 & 16 & 16.2 & 18.7 & 17.4 & 0.8 \\
\hline Interorbital distance & 38.2 & 16 & 32.7 & 39.0 & 36.8 & 1.7 \\
\hline Cleithral width & 72.8 & 16 & 65.7 & 73.0 & 69.9 & 2.4 \\
\hline \multicolumn{7}{|c|}{ Counts } \\
\hline Dorsal plates left & 20 & 14 & 18 & 22 & 20.0 & 1.1 \\
\hline Dorsal plates right & 20 & 14 & 19 & 21 & 20.4 & 0.6 \\
\hline Mid-dorsal plate left & 18 & 14 & 17 & 19 & 18.0 & 0.6 \\
\hline Mid-dorsal plate right & 18 & 14 & 17 & 19 & 17.8 & 0.6 \\
\hline Median plates left & 23 & 14 & 22 & 23 & 22.9 & 0.4 \\
\hline Median plates right & 23 & 14 & 21 & 23 & 22.7 & 0.6 \\
\hline Mid-ventral plates left & 18 & 14 & 17 & 19 & 18.1 & 0.8 \\
\hline Mid-ventral plates right & 18 & 14 & 17 & 20 & 18.6 & 0.8 \\
\hline Ventral plates right & 20 & 13 & 19 & 21 & 20.7 & 0.6 \\
\hline Ventral plates left & 19 & 13 & 19 & 22 & 20.3 & 0.9 \\
\hline Predorsal plates & 4 & 16 & 4 & 5 & 4.1 & 0.3 \\
\hline Left premaxillary teeth & 9 & 16 & 7 & 12 & 8.8 & 1.4 \\
\hline Right premaxillary teeth & 6 & 16 & 6 & 10 & 8.2 & 1.4 \\
\hline Left dentary teeth & 7 & 16 & 5 & 10 & 7.2 & 1.2 \\
\hline Right dentary teeth & 9 & 16 & 4 & 9 & 6.9 & 1.4 \\
\hline Dorsal-fin branched rays & 7 & 16 & 6 & 7 & 6.9 & 0.3 \\
\hline Pectoral-fin branched rays & 6 & 16 & 6 & 6 & 6.0 & 0.0 \\
\hline Pelvic-fin branched rays & 5 & 16 & 5 & 5 & 5.0 & 0.0 \\
\hline Anal-fin branched rays & 5 & 16 & 4 & 5 & 4.9 & 0.3 \\
\hline Caudal-fin branched rays & 14 & 16 & 14 & 14 & 14.0 & 0.0 \\
\hline
\end{tabular}

and P. muriaensis by the presence of unicuspid teeth behind the series of bicuspid teeth of the dentary and premaxillary. Parotocinclus bidentatus differs from species of Niobichthys by the absence of thoracic plates; presence of small plates on thorax and abdomen ( $v s$. large plates) and a snout tip plated formed by the rostral plate (vs. snout tip naked). Parotocinclus bidentatus differs from species of Epactionotus by the presence of small plates medially on the abdomen ( $v s$. abdomen naked medially), small interorbital distance entering more than two times in the maximal body width, and a straight head profile (vs. concave). Parotocinclus bidentatus differs from species of Eurycheilichthys by the presence of a single rostral plate at the snout tip ( $v s$. several plates), medial (and lateral) exposure of the ventral surface of the pectoral girdle (vs. ventral exposure restricted to lateral portion of girdle) and six branched rays in the pectoral fin ( $v s$. seven rays). Parotocinclus bidentatus differs from $P$. collinsae by the absence of an adipose fin and the irregularly distributed small plates on the abdomen ( $v s$. three rows of six plates). Parotocinclus bidentatus differs from P. muriaensis by a small cleithral width (maximum of $27 \%$ SL), a proximal and a distal relatively large blotch (vs. small dark dots) on the first two branched rays of the pectoral fin, and complete exposition of the pectoral girdle ( $v S$. partly exposed, Fig. 1 and 2).

Additionally the new species can be distinguished from other species of Parotocinclus by the absence of an adipose fin (except for $P$. muriaensis and occasionally $P$. spilurus) and the small number of bicuspid premaxillary (6-12, usually 9$)$ and dentary (4-10, usually 7) teeth (except for P. muriaensis).

Description. Morphometric and meristic data presented in Table 1. Dorsal profile slightly convex from tip of snout to dorsal-fin origin, straight at dorsal-fin base, straight and parallel to ventral profile of caudal peduncle from end of dorsalfin base to caudal-fin base. Ventral profile from snout to anus straight, transversely flat. Snout tip rounded, rostrum straight. Greatest body depth at dorsal-fin origin 14.7-16.7\% SL. Crosssection of body between pectoral and pelvic fins dorsally rounded and ventrally flat; cross-section of caudal peduncle ellipsoid anteriorly, more flattened posteriorly.

Head depressed. Eye moderately small, positioned midway between snout tip and pterotic-supracleithrum posterior margin; distance between orbit margin and ventral surface of head greater than orbital diameter. Dorsal iris diverticulum present. Lateral ethmoid exposed posterior to nostril between frontal bone and prefrontal plate, with two rows of odontodes. Enlarged pterotic fenestrae of varied shape and size scattered over surface of pterotic-supracleithrum except for small postero-dorsal edge. Swim bladder capsule with small opening between supraoccipital and pterotic-supracleithrum.

Dorsal fin I,7; its origin slightly posterior to pelvic-fin origin; when depressed reaching beyond vertical line through end of anal-fin base. V-shaped dorsal-fin spinelet present, articulated with roughly hexagonal nuchal plate. Pectoral fin I,6; reaching middle of pelvic-fin length, when depressed. Slit present above pectoral-fin insertion and below lateral process of cleithrum. Pelvic fin i,5; when depressed reaching anal-fin origin in males, reaching beyond anus in females. Dorsal surface of unbranched pelvic-fin ray with skin flap in males. Anal fin i,5. Caudal fin i,7,7,i. Fin notched, ventral caudal-fin lobe slightly longer than dorsal lobe. Total vertebrae 30 (in one c\&s specimen).

Lateral line almost complete; pored tubes visible from pterotic-supracleithrum to caudal peduncle; one plate, usually sixth or seventh, without lateral line tube, but canal may continue in skin. Abdomen with numerous small dermal platelets, without naked area. Pectoral girdle entirely exposed ventrally; coracoids entirely covered with odontodes; arrector fossae round, small, not meeting at midline, covered by skin (Fig. 2). Odontodes evenly distributed, regularly arranged on head and body. Enlarged odontodes on anterior and lateral margin of snout, bordering upper lip.

Premaxillary teeth usually 9 ; dentary teeth usually 7 . Accessory unicuspid teeth present internally to main tooth cup in premaxilla and dentary. Oral disk roundish; lower lip covered with papillae; papillae small, except for large papilla located posterior to dentary symphysis; upper lip one third of lower 
lip; width of lower lip 38.0-53.1\% HL, length 23.1-28.5\% HL.

Adipose fin represented by two unpaired plates (c\&s specimen); some specimens with small elevation at that site which may be less pigmented then surrounding area.

Coloration in alcohol. Coloration better preserved in smaller specimens. Ground color brown to ochre dorsally, yellowish ventrally. Dorsal surface of head from snout tip to pteroticsupracleithrum with darker pigmentation, except for cheeks and triangular clear area extending from snout tip to eyes. Dark pigmentation at dorsal-fin base and unbranched dorsalfin ray; dark triangular blotch extending from proximal onethird of first dorsal-fin ray to base of sixth branched dorsalfin ray; remaining area of fin with small dark spots. Skin near slit at base of pectoral fin with dark chromatophores. First and second branched rays of pectoral fin with two dark patches. Caudal fin with dark trapezoid to triangular area at base extending two-thirds of fin length. One small isolated blotch on dorsal caudal-fin lobe and one on ventral lobe, sometimes continuous with large anterior spot. Anal fin with three large spots along anterior margin.

Distribution. Parotocinclus bidentatus is known from its type locality, at rio Pirapetinga, near Resende, and from rio Calçado, near Três Rios, rio Paraíba do Sul basin, Rio de Janeiro, Brazil (Fig. 6). Based on this limited sample it may be hypothesized that $P$. bidentatus was originally distributed on the low courses of small tributaries of the rio Paraíba do Sul draining the southeastern slope of the Serra da Mantiqueira and the northern slopes of Serra da Bocaina and Serra dos Órgãos. However, the paucity of specimens in museum collections suggests that the species may have a reduced distribution.

Etymology. The specific epithet $P$. bidentatus signifies two teeth and is used as a Latin adjective. The name refers to the presence of two types of dentition, namely the usual series of oral teeth and accessory patch of teeth on the upper and lower jaws.

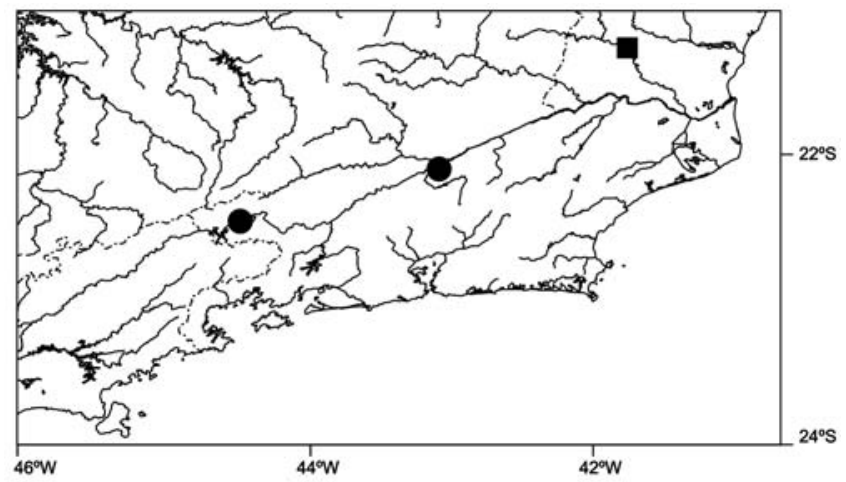

Fig. 6. Paraíba do Sul drainage illustrating collecting localities of Parotocinclus bidentatus (circles, type locality on the left) and $P$. muriaensis (squares). Each symbol may present more than one sample or locality.

\section{Parotocinclus muriaensis, new species}

Fig. 7

Holotype. MNRJ 28528, $31.0 \mathrm{~mm}$ SL, rio Muriaé river (left bank tributary of rio Paraíba do Sul), near intersection of highways BR-356 and RJ-186, $20 \mathrm{~km}$ downstream from Itaperuna, approx. $21^{\circ} 15 " \mathrm{~S} 41^{\circ} 45^{\prime \prime} \mathrm{W}$, Município de Itaperuna, Rio de Janeiro State, Brazil, D. F. Moraes Jr. et al., 24 Oct 1989.

Paratypes. MNRJ 14753, 3, 26.1-28.8 mm SL, 1 c\&s, 27.3 mm SL, 1 with deformed snout, collected with the holotype.

Diagnosis. Parotocinclus muriaensis can be distinguished from all other Hypoptopomatinae except Niobichthys, Epactionotus, Eurycheilichthys, Parotocinclus collinsae, and P. bidentatus by the presence of unicuspid teeth behind the series of bicuspid teeth of the dentary and premaxillary. Parotocinclus muriaensis differs from species of Niobichthys by the absence of thoracic plates; the presence of small plates on the thorax and abdomen ( $v s$. large plates) and a plated snout tip formed by the rostral plate (vs. naked snout tip). Parotocinclus muriaensis differs from species of Epactionotus by the presence of small plates medially on the abdomen ( $v s$. abdomen naked medially), a small interorbital distance entering more than two times in the maximal body width, and a straight head profile (vs. concave). Parotocinclus muriaensis differs from species of Eurycheilichthys by the presence of a single rostral plate at the snout tip ( $v s$. several plates), medial (and lateral) exposure of the ventral surface of the pectoral girdle (vs. ventral exposure restricted to lateral portion of girdle) and six branched rays in the pectoral fin (vs. seven rays). Parotocinclus muriaensis differs from $P$. collinsae by the absence of the adipose fin, and the irregularly distributed small plates on the abdomen ( $v s$. three rows of six plates). Parotocinclus muriaensis differs from $P$. bidentatus by a large cleithral width (minimum of $28 \% \mathrm{SL}$ ), presence of small dark dots on the first two branched rays of the pectoral fin ( $v s$. a proximal and a distal relatively large blotch on the first two branched rays), and a medially naked area on the pectoral girdle (Fig. 1).

Additionally the new species can be distinguished from other species of Parotocinclus by the absence of the adipose fin (except for P. bidentatus and occasionally P. spilurus), and the small number of bicuspid premaxillary (10-12, usually 1011 ) and dentary (7-8, usually 8 ) teeth (except for P. bidentatus).

Description. Morphometric and meristic data presented in Table 2. Dorsal profile slightly convex to straight from snout tip to dorsal-fin origin, straight at dorsal-fin base, straight and parallel to ventral profile of caudal peduncle from end of dorsal-fin base to caudal-fin base. Ventral profile from snout to anus straight, transversely flat. Snout tip rounded, rostrum straight. Greatest body depth at dorsal-fin origin, 15.8-17.4\% SL. Crosssection of body between pectoral and pelvic fins dorsally rounded and ventrally flat; cross-section of caudal peduncle ellipsoid anteriorly, more flattened posteriorly.

Head depressed. Eyes moderately small, positioned midway between snout tip and pterotic-supracleithrum posterior 
margin; distance between orbit margin and ventral surface of head greater than orbital diameter. Dorsal iris diverticulum present. Presence of an opening between supraoccipital and pterotic-supracleithrum, where third bony structure emerges on surface of cranium. Lateral ethmoid exposed posterior to nostril between frontal bone and prefrontal plate, with two rows of odontodes. Enlarged pterotic fenestrae of varied shape and size scattered over surface of pterotic-supracleithrum, except for postero-dorsal edge. Swim bladder capsule with small opening between supraoccipital and pterotic-supracleithrum.

Dorsal fin I,7; its origin slightly posterior to pelvic-fin origin; when depressed reaching beyond vertical line through end of anal-fin base. V-shaped dorsal-fin spinelet present. articulated with roughly hexagonal nuchal plate. Pectoral fin I,6; reaching middle of pelvic-fin length when depressed. Slit present above pectoral-fin insertion and below lateral process of cleithrum. Pelvic fin i,5; when depressed reaching anal-fin origin in males, reaching beyond anus in females. Dorsal surface of unbranched pelvic-fin ray with skin flap in males. Anal fin i,5. Caudal fin i,7,7,i. Fin notched, ventral caudal-fin lobe slightly longer than dorsal lobe. Total vertebra 28 (in one c\&s specimen).

Lateral line almost complete; pored tubes visible from pterotic-supracleithrum to caudal peduncle; one plate, usually sixth or seventh, without lateral line tube, but canal may continue in skin. Abdomen with numerous small dermal plates. Median portion of pectoral girdle not exposed ventrally; arrector fossae ellipsoid, large (length of pectoral girdle), meeting at midline, covered by skin (Fig. 1). Odontodes evenly distributed, regularly arranged on head and body. Enlarged

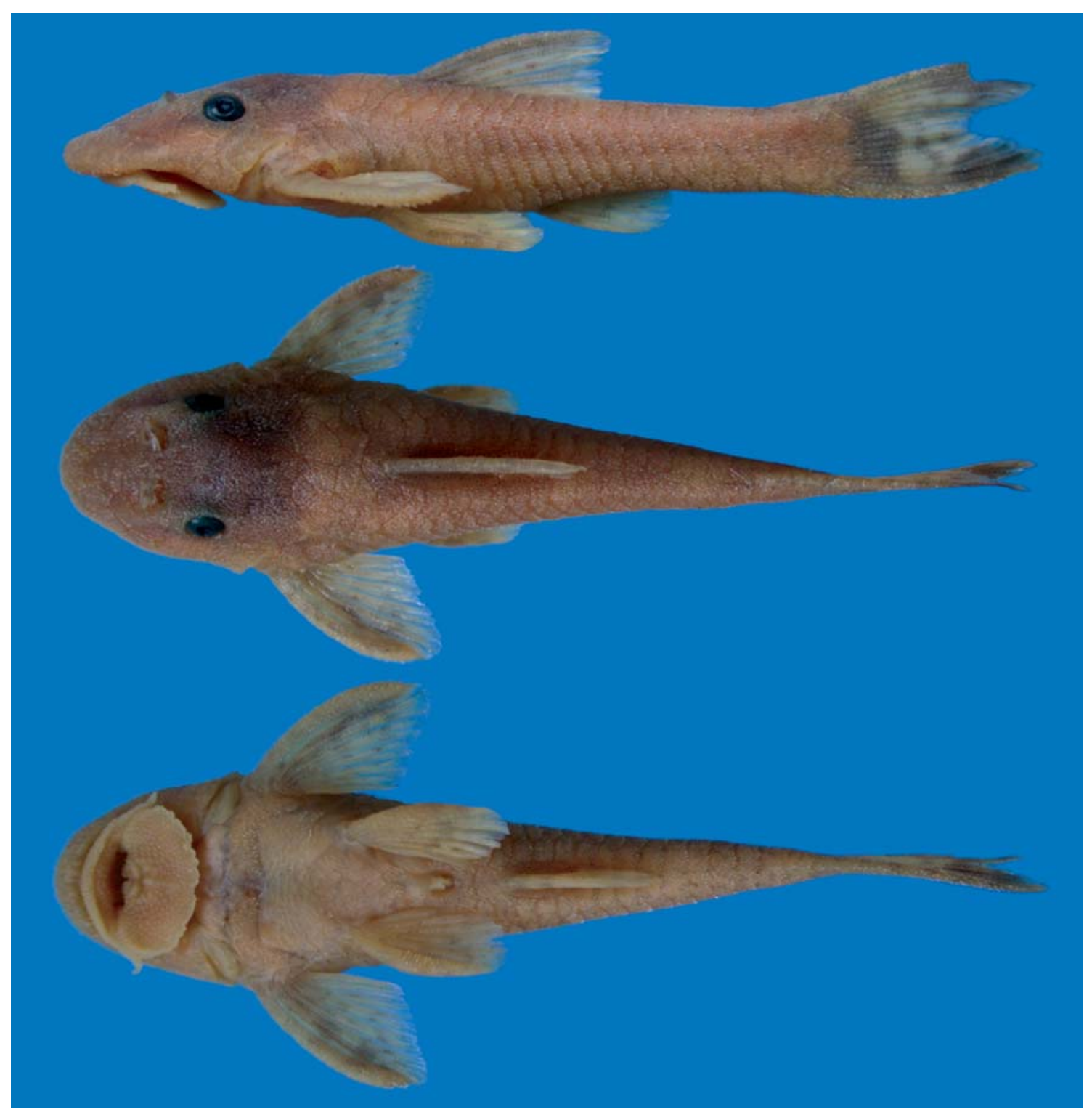

Fig. 7. Parotocinclus muriaensis, holotype MNRJ 28528, $31.0 \mathrm{~mm}$ SL. Brazil: Rio de Janeiro State: rio Muriaé river (left bank tributary of rio Paraíba do Sul), near intersection of highways BR-356 and RJ-186, 20 km downstream from Itaperuna, Município de Itaperuna. 
Table 2. Morphometric and meristic data for Parotocinclus muriaensis. $\mathrm{Hol}=$ Holotype.

\begin{tabular}{|c|c|c|c|c|c|c|}
\hline & Hol & $\mathbf{N}$ & Low & High & Mean & SD \\
\hline Standard length & 31.0 & 4 & 26.1 & 31.0 & 28.4 & 2.1 \\
\hline Head length & 11.3 & 4 & 10.3 & 11.3 & 10.6 & 0.5 \\
\hline \multicolumn{7}{|c|}{ Percent of Standard Length } \\
\hline Predorsal length & 46.1 & 4 & 45.6 & 47.7 & 46.4 & 0.9 \\
\hline Head length & 36.4 & 4 & 36.4 & 39.5 & 37.6 & 1.3 \\
\hline Dorsal-fin spine length & 25.9 & 4 & 25.7 & 28.6 & 26.6 & 1.4 \\
\hline Dorsal-fin base length & 14.4 & 4 & 13.8 & 14.4 & 14.1 & 0.2 \\
\hline Trunk length & 13.3 & 4 & 13.3 & 14.8 & 13.8 & 0.7 \\
\hline Pectoral-fin length & 25.7 & 4 & 25.7 & 29.0 & 27.2 & 1.7 \\
\hline Abdominal length & 20.3 & 4 & 20.3 & 22.3 & 21.2 & 0.8 \\
\hline Caudal-peduncle length & 33.5 & 4 & 31.4 & 33.5 & 32.5 & 0.9 \\
\hline Caudal-peduncle depth & 13.5 & 4 & 12.5 & 13.5 & 13.2 & 0.5 \\
\hline \multicolumn{7}{|c|}{ Percent of Head Length } \\
\hline Head depth & 43.4 & 4 & 43.4 & 44.0 & 43.7 & 0.3 \\
\hline Snout length & 58.1 & 4 & 54.3 & 58.1 & 56.1 & 1.6 \\
\hline Horizontal eye diameter & 16.2 & 4 & 16.2 & 17.7 & 16.9 & 0.7 \\
\hline Interorbital distance & 36.0 & 4 & 33.6 & 36.8 & 35.4 & 1.4 \\
\hline Cleithral width & 80.2 & 4 & 73.7 & 80.2 & 76.2 & 2.9 \\
\hline \multicolumn{7}{|c|}{ Counts } \\
\hline Dorsal plates left & 21 & 5 & 20 & 21 & 20.2 & 0.4 \\
\hline Dorsal plates right & 21 & 5 & 20 & 21 & 20.2 & 0.4 \\
\hline Mid-dorsal plate left & 18 & 5 & 18 & 19 & 18.4 & 0.5 \\
\hline Mid-dorsal plate right & 18 & 5 & 18 & 19 & 18.2 & 0.4 \\
\hline Median plates left & 22 & 5 & 22 & 23 & 22.6 & 0.5 \\
\hline Median plates right & 23 & 5 & 23 & 23 & 23.0 & 0.0 \\
\hline Mid-ventral plates left & 19 & 5 & 18 & 19 & 18.8 & 0.4 \\
\hline Mid-ventral plates right & 19 & 5 & 18 & 19 & 18.6 & 0.5 \\
\hline Ventral plates right & 20 & 5 & 20 & 21 & 20.2 & 0.4 \\
\hline Ventral plates left & 20 & 5 & 18 & 20 & 19.2 & 0.8 \\
\hline Predorsal plates & 4 & 4 & 4 & 4 & 4.0 & 0.0 \\
\hline Left premaxillary teeth & 12 & 4 & 10 & 12 & 11.0 & 0.8 \\
\hline Right premaxillary teeth & 10 & 4 & 10 & 12 & 10.8 & 1.0 \\
\hline Left dentary teeth & 8 & 4 & 7 & 8 & 7.8 & 0.5 \\
\hline Right dentary teeth & 7 & 4 & 7 & 8 & 7.8 & 0.5 \\
\hline Dorsal-fin branched rays & 7 & 4 & 7 & 7 & 7.0 & 0.0 \\
\hline Pectoral-fin branched rays & 6 & 4 & 6 & 6 & 6.0 & 0.0 \\
\hline Pelvic-fin branched rays & 5 & 4 & 5 & 5 & 5.0 & 0.0 \\
\hline Anal-fin branched rays & 5 & 4 & 5 & 5 & 5.0 & 0.0 \\
\hline Caudal-fin branched rays & 14 & 4 & 14 & 14 & 14.0 & 0.0 \\
\hline
\end{tabular}

odontodes on anterior and lateral margins of snout, bordering upper lip.

Premaxillary teeth usually 10-11; dentary teeth usually 8 . Accessory unicuspid teeth present internally to tooth cup in premaxilla and dentary. Oral disk roundish; lower lip covered with papillae; papillae small, except for large papilla located posterior to dentary symphysis; upper lip one-third of lower lip; width of lower lip 45.2-53.8\% HL, length 20.5-27.6\% HL.

Adipose fin represented by unpaired plate (c\&s specimen); in some specimens small elevation at that site which may be less pigmented than surrounding area.

Coloration in alcohol. Coloration better preserved in smaller specimens. Ground color brown to ochre dorsally, yellowish ventrally. Pigmentation darker on dorsal surface of head between nostrils and pterotic-supracleithra, base of dorsal fin, skin surrounding slit at base of pectoral fin. Fin rays with regularly distributed brownish dots. Large dark, nearly trapezoid area at caudal-fin base extending posteriorly one-third of caudal-fin length; irregular, isolated dark blotch at tips of upper and lower caudal-fin lobes; horizontal black line sometimes present near middle caudal-fin rays.
Distribution. Parotocinclus muriaensis is known only from its type locality, at rio Muriaé near Itaperuna, a left tributary of the rio Paraiba do Sul basin, Rio de Janeiro, Brazil (Fig. 6).

Etymology. The specific epithet refers to the rio Muriaé, where this new species was collected.

Unidentified specimens. Two specimens (MNRJ 16048, 26.0$28.9 \mathrm{~mm} \mathrm{SL}$ ) from córrego da Areia in the county of Chiador are similar to the two new species described above. They differ by the smaller cleithral width (23.9 and $25.8 \%$ SL $v s$. 28.1-29.2\% SL in P. muriaense, 24.7-26.4\% SL in P. bidentatus) and head depth (34.1 and 39.2\% HL vs. 43.4-44.0\% HL in $P$. muriaense, 39.9-47.5\% HL in P. bidentatus), and the lower lip is wider than in P. bidentatus (29.4 and 32.5\% HL vs. 23.1$27.3 \% \mathrm{HL}$ ). The two specimens are more similar to P. bidentatus than to P. muriaensis. However, due to their small size, we cannot ascertain whether they represent a third species or simply a local variation of one of the described species.

\section{Discussion}

In all equally parsimonious trees (Fig. 3) Parotocinclus bidentatus and P. muriaensis form a monophyletic pair of sister taxa that is more closely related to a subset of species of Parotocinclus than to any other genus of the subfamily Hypoptopomatinae. The subset includes $P$. maculicauda which is the type species of Parotocinclus. Based on these phylogenetic results we decided to describe the two new species as members of the genus Parotocinclus, although we are aware that the examined specimens lack a fully developed adipose fin, which is traditionally used as a diagnostic character in the identification of the genus. Within Parotocinclus, a rudimentary adipose fin is found in P. spilurus (Fowler 1941) from the state of Ceará, in northeastern Brazil. This species differs from the two new species by having the abdomen covered laterally by a row of elongated plates and medially by irregular plates (vs. only small plates), the interorbital distance entering less than two times in the maximal body width and the head rounded in dorsal view.

Three characters support a close relationship between the type species of Parotocinclus and the subset of species that includes P. bidentatus and P. muriaensis (Fig. 4, Clade 48). In these species, the mid-dorsal lateral plate series is continued along most of the median series (character 32). Truncation of the mid-dorsal series was illustrated by Schaefer (1997: fig. 1). According to Schaefer (1998), truncation of the mid-dorsal series is a synapomorphy of Acestridium, Hypoptopoma, Nannoptopoma, Oxyropsis and Niobichthys. However, we also found that the mid-dorsal series is truncated in Hisonotus notatus and Otothyris travassosi, as well in several undescribed taxa. The condition observed in Parotocinclus is thus more parsimoniously interpreted as a non-unique synapomorphy of Parotocinclus. The hypothesis is also supported by the relatively small size of the ventral lamina of the fourth infraorbital bone (character 37). This character was illustrated by Schaefer 
(1991: Fig. 11). According to our phylogenetic hypothesis (Fig. 4) the condition observed in Parotocinclus is a secondary reversal. Finally, the close relationship between Parotocinclus and new species is supported by the presence of azygous spinelets on the caudal peduncle that correspond to the adipose fin (character 52). In spite of the absence of a fully developed adipose-fin membrane, the presence of rudimentary azygous spinelets is most parsimoniously regarded as homologous with the fully developed adipose-fin spine of most species of Parotocinclus.

According to our new parsimony analysis Parotocinclus is not a monophyletic genus. Parotocinclus jumbo is not closely related to $P$. maculicauda, but is positioned, instead, as a basal lineage of the Hypoptopomatinae (Fig. 3). Additionally, Parotocinclus collinsae is not closely related to $P$. maculicauda, and may be more closely related to Hypoptopoma and four other genera (Fig. 3). The polyphyletic nature of Parotocinclus was previously suggested by Schaefer \& Provenzano (1993), and Britski \& Garavello (2002). Parotocinclus jumbo and $P$. collinsae may eventually be transferred to new genera. Redefinition of the limits of Parotocinclus, however, is not the aim of this study, and only one-third of the species currently assigned to the genus were included in our phylogenetic analyis. Since the last revision of Parotocinclus by Garavello (1977), nine new species have been described. A phylogenetic revision of Parotocinclus is currently the object of a doctoral study by Pablo Lehmann (MCP). Based on our results, however, $P$. bidentatus and $P$. muriaensis are closely related to the type of the genus, and they are likely to remain as a part of the genus Parotocinclus.

The phylogenetic results of the present study also differ significantly from the hypothesis of interrelationships among Hypoptopomatinae presented by Schaefer $(1991,1998)$. The tribe Othothyrini is not monophyletic. Its representatives comprise a paraphyletic group in relation to the tribe Hypoptopomatini. Eurycheilichthys pantherinus occupies a basal position relative to all other examined species except Parotocinclus jumbo. Our results differ from those of Schaefer $(1991,1998)$ perhaps because we included more species and more characters in the analysis, and because we used actual species as terminal taxa instead of coding terminal taxa as composite units. Additionally, we had to delete Taxon 3 from Schaefer's matrix, because we did not have specimens to code the newly included characters. The deletion resolved some confusion, but unfortunately we may have lost useful information, as Taxon 3 was the most basal taxon of the tribe Othotyrini (Schaefer, 1998: fig. 3). Schaefer (1998) discussed the impact of deletion and insertion of species on hypotheses of Hypotopomatinae phylogeny. Our results are clearly affected by the inclusion of additional characters, but it appears that the greater impact on tree topology was caused by the inclusion of Parotocinclus jumbo, P. collinsae, and the undescribed species from Central Brazil.

Comparative material. Acestridium discus: MZUSP 85320 (1 c\&s, 56.6 mm), MZUSP 85321 (2 c\&s), MZUSP 85322 (1), MNRJ 1084
(2 c\&s). Acestridium marini: MZUSP 74275 (7, 1 c\&s). Corumbataia tocantinensis: MNRJ 13292 (52, 3 c\&s). Epactionotus bilineatus: MCP 29116 (28, 1 c\&s), MCP 25688 (29, 2 c\&s). Epactionotus gracilis: MCP 11615 (17, 2 c\&s). Epactionotus itaimbezinho: MCP 26208 (12, 2 c\&s). Eurycheilichthys pantherinus: MNRJ 18865 (32, $2 \mathrm{c \& s}$ ). Hisonotus notatus MNRJ 15741 (126, 2 c\&s). Hypoptopoma sp.: MNRJ 24310 (5, 1 c\&s). Microlepidogaster perforatus: MCP 17717 (5, 1 c\&s, 33,3). Nannoptopoma spectabilis: MCNG 26579 (2 c\&s). Nannoptopoma sternoptychum: CBF 4058 (1 c\&s). Niobichthys ferrarisi: MCP 34810 (1 c\&s). Neoplecostomus microps: MNRJ 14431 (7, 1 c\&s). Otocinclus vittatus: MNRJ 25278 (46, 2 c\&s). Otothyris travassosi: MNRJ 22947 (70, 2 c\&s). Oxyropsis wrightiana: MCP 26208 (14, 1 c\&s), MCP 34503 (3 c\&s). Parotocinclus collinsae: ANSP 175923 (1 c\&s, 1 alcohol). Parotocinclus cearensis: MNRJ 8689 (103, 2 c\&s). Parotocinclus cesarpintoi: MNRJ 1154 (62). Parotocinclus doceanus: MCP 29500 (16, 2 c\&s). Parotocinclus jumbo: MZUSP 69514 (7, 2 skeleton, 1 c\&s). Parotocinclus haroldoi: MNRJ 11383 (18, 2 c\&s). Parotocinclus maculicauda: MNRJ 24104 (13, 1 c\&s), MCP 17605 (5, 2 c\&s), MCP 20075 (6, 2 c\&s). Parotocinclus spilosoma: MCP 30689 (50, 3 c\&s). Parotocinclus sp.: MNRJ 16048 (2). Pseudotocinclus tietensis: MNRJ 19990 (7, 1 c\&s), MZUSP 38114, MZUSP 63643 (1 c\&s), MZUSP 42389 (39, 6 digital radiographs). Pseudotothyris obtusa MNRJ 24355 (28, 2 c\&s, 29.9 and $30.5 \mathrm{~mm})$; Schizolecis guntheri: MNRJ 24246 (38, 2 c\&s); Unnamed taxon 1: MNRJ 24969 (31, 2 c\&s). Unnamed taxon 2: MNRJ 24987 (99, 2 c\&s). Unnamed taxon 3: MNRJ 24642 (50, 2 c\&s). Unnnamed taxon 4: MNRJ 23631 (22, 2 c\&s). Unnamed taxon 5: MNRJ 23630 (14, 2 c\&s). Unnamed taxon 6: MNRJ 23279 (26, 2 c\&s). Unnamed taxon 7: MNRJ 23307 (25, 2 c\&s).

\section{Acknowledgements}

We are most thankful to Marcelo R. Britto (MNRJ) for the initial coding of the data matrix and discussions about catfish morphology. Cristiano R. Moreira (MZUSP) prepared digital radiographs of Pseudotocinclus tietensis specimens. We thank also Roberto E. Reis (MCP), Pablo C. Lehmann (MCP) and ANSP for the specimens of Parotocinclus collinsae. Osvaldo T. Oyakawa (MZUSP) and Roberto E. Reis provided access to cleared and stained specimens of Hypoptopo-matinae at their institutions. Priscila Gomes (MNRJ) provided curatorial assistance. Cristiano R. Moreira (MZUSP) provided digital radiographs of Pseudotocinclus. This study was partially supported by grants from Conselho Nacional de Desenvolvimento Científico e Tecnológico (CNPq, proc. 473652/2003-0, 523237/ 95-2, (PAB)) and Programa de Apoio a Núcleos de Excelência (PRONEX, proc. CNPq 661058/1997-2, with N.A. Menezes).

\section{Literature Cited}

Boeseman, M. 1968. The genus Hypostomus La Cepède, 1803, and its Surinam representatives (Siluriformes: Loricariidae). Zoologische Verhandelingen, 99: 1-89, pls. 1-18.

Britski, H. A. \& J. C. Garavello. 2002. Parotocinclus jumbo, a new species of the subfamily Hypoptopomatinae from northeastern Brazil (Ostariophysi: Loricariidae). Ichthyological Exploration of Freshwaters, 13(3): 279-288.

Fowler, H. W. 1941. A collection of fresh-water fishes obtained in eastern Brazil by Dr. Rodolpho von Ihering. Pro- 
ceedings of the Academy of Natural Sciences of Philadelphia, 93: 123-199.

Garavello, J. C. 1977. Systematics and geographical distribution of the genus Parotocinclus Eigenmann \& Eigenmann, 1889 (Ostariophysi, Loricariidae). Arquivos de Zoologia, 28(4): 1-37.

Hennig, W. 1966. Phylogenetic Systematics. University of Illinois Press, Urbana. 263p.

Leviton, A. E., R. H. Gibbs Jr., E. Heal \& C. E. Dawson. 1985. Standards in herpetology and ichthyology. Part I. Standard symbolic codes for institutional resource collections in herpetology and ichthyology. Copeia, 1985(4): 802-832.

Reis, R. E. \& S. A. Schaefer. 1992. Eurycheilus pantherinus (Siluroidei: Loricariidae), a new genus and species of Hypoptopomatinae from southern Brazil. Copeia, 1992(1): 215-223.

Reis, R. E. \& S. A. Schaefer. 1998. New cascudinhos from southern Brazil: Systematics, endemism, and relationships (Siluriformes, Loricariidae, Hypoptopomatinae). American Museum Novitates, 3254: 1-25.

Schaefer, S. A. 1991. Phylogenetic analysis of the loricariid subfamily Hypoptopomatinae (Pisces: Siluriformes: Loricariidae), with comments on generic diagnosis and geographic distribution. Zoological Journal of the Linnean Society, 102: 1-41.

Schaefer, S. A. 1997. The Neotropical cascudinhos: systematics and biogeography of the Otocinclus catfishes
(Siluriformes: Loricariidae). Proceedings of the Academy of Natural Sciences of Philadelphia, 148: 1-120.

Schaefer, S. A. 1998. Conflict and resolution: impact of new taxa on phylogenetic studies of the neotropical cascudinhos (Siluroidei: Loricariidae). Pp. 375-400 In: L. R. Malabarba, R. E. Reis, R. P. Vari, Z. M. Lucena \& C. A. Lucena (Eds.) Phylogeny and classification of neotropical fishes. Edipucrs, Porto Alegre. 603 p.

Schaefer, S. A. \& F. Provenzano. 1993. The Guyana Shield Parotocinclus: systematics, biogeography, and description of a new Venezuelan species (Siluroidei: Loricariidae). Ichthyological Exploration of Freshwaters, 4(1): 39-56.

Schaefer, S. A. \& F. Provenzano. 1998. Niobichthys ferrarisi, a new genus and species of armored catfish from southern Venezuela (Siluriformes: Loricariidae). Ichthyological Exploration of Freshwaters, 8(3): 221-230.

Schmidt, R. E. \& C. J. Ferraris, Jr. 1985. A new species of Parotocinclus (Pisces: Loricariidae) from Guyana. Proceedings of the Biological Society of Washinton, 98(2): 3241-3246.

Swofford, D. L. 2003. PAUP*. Phylogenetic Analysis Using Parsimony (* and Other Methods). Version 4. Sinauer Associates, Sunderland, Massachusetts.

Taylor, W. R. \& G. C. Van Dyke, 1985. Revised procedures for staining and clearing small fishes and other vertebrates for bone and cartilage study. Cybium, 9: 107-119.

Received August 2005 Accepted november 2005

Appendix. Data matrix used for the phylogenetic analysis:

\begin{tabular}{|c|c|c|c|c|c|c|}
\hline Loricariinae, Ancistrinae e Hypostominae & 0000000000 & $00 ? 0000000$ & 0000000000 & $0 ? 00000000$ & $0 ? 00000000$ & 0000000 \\
\hline Neoplecostomus microps & 0000000000 & 0000000000 & 0000000000 & 0000000000 & 0000000000 & 0000001 \\
\hline Acestridium discus & 0020000000 & 0021001011 & -002102113 & 1121010120 & 0000101010 & 1220101 \\
\hline Hypoptopoma sp. $c f$. H. Guntheri & 0100111010 & 0011111010 & 1102102113 & 0101010220 & 1110101010 & 1220101 \\
\hline Nannoptopoma specabilis & 0100111010 & 0011111010 & 1101102103 & 0101010220 & 1100101010 & 1220101 \\
\hline Oxyropsis wrightiana & 0100111000 & 0011111011 & -002102113 & 0101010121 & 0110100010 & 1220101 \\
\hline Otocinclus vitattus (?) & 1201101001 & 1011110011 & -000000003 & 0001000120 & 0020000010 & 1220101 \\
\hline Niobichthys ferrarisi & 0010111000 & $001110 ? 010$ & 0001102013 & 0120010201 & 0101000010 & $122-101$ \\
\hline Hisonotus notatus & 0010100001 & 1021000100 & 0000000002 & 0111101020 & 0000000000 & 1220101 \\
\hline Microlepidogaster perforatus & 0010100001 & 1021000100 & 0000011102 & 1011001000 & 0100000000 & $122-001$ \\
\hline Pseudotocinclus sp. & 0010100001 & 1020000100 & 0000011002 & 1000000000 & 0000001001 & $122-011$ \\
\hline Parotocinclus cearensis & 0000100001 & 0020000100 & 0000000001 & 0001100020 & 0000001000 & 1020011 \\
\hline P. cesarpintoi & 0000100001 & 0020000100 & 0000000002 & 0001100020 & 0000000000 & 1020011 \\
\hline P. collinsae & 0000100001 & 0020000100 & 0000000003 & 0001001020 & 0001000010 & 1021101 \\
\hline P. doceanus & 0000100001 & 0020000100 & 0000000002 & 1001100020 & 0000000000 & 1020101 \\
\hline P. haroldoi & 0000100001 & 0020000100 & 0000000002 & 0001100020 & 0000000000 & 1020011 \\
\hline P. jumbo & 1000100000 & 0020000100 & 0000011001 & 0001001000 & 0000100000 & 0010010 \\
\hline P. maculicauda & 0010100001 & 0010000100 & 0000000002 & 1001100020 & 0000000000 & 1020101 \\
\hline P. muriaensis & 0000100001 & 0020000100 & 0000000001 & 1001100020 & 0001000000 & 1120001 \\
\hline P. bidentatus & 0000100001 & 0020000100 & 0000000002 & 1001000020 & 0001000000 & 1120001 \\
\hline Otothyris travassossi & 1010100101 & 1120000100 & 0010001003 & 1100001010 & 0100000111 & $122-110$ \\
\hline Pseudotothyris obtusa & 0000100101 & $112000 ? 100$ & 0010002002 & 1000001010 & 0100000011 & $122-011$ \\
\hline Schizolecis guntheri & 0010100001 & 0120000100 & 0010002002 & 1000001000 & 0100100011 & $122-010$ \\
\hline Eurycheilichthys pantherinus & 0000100001 & 0020000100 & 0000001001 & 1000001000 & 0001010000 & $121-001$ \\
\hline Epactionotus bilineatus & 0010100001 & 0020000100 & 0000011002 & 1001101020 & 0001100000 & 1220011 \\
\hline Corumbataia tocantinensis & 0000100000 & 1021000100 & 0000101003 & 1000001000 & 0000100100 & $122-011$ \\
\hline Unnamed taxon 1 & 0000100001 & 0020100100 & 0000000002 & 1101001020 & 0000000010 & 1221101 \\
\hline Unnamed taxon 2 & 0000100001 & 0020100100 & 0000000002 & 1101001020 & 0000000000 & 1220101 \\
\hline Unnamed taxon 3 & 0010100001 & 0020000100 & 0000000002 & 0100001020 & 0000000000 & $122-101$ \\
\hline Unnamed taxon 4 & 0010100001 & 1020000100 & 0000100002 & 0100001020 & 0000000000 & $122-011$ \\
\hline Unnamed taxon 5 & 0000100001 & 0020000100 & 0000000002 & 1101001020 & 0000000010 & 1221101 \\
\hline Unnamed taxon 6 & 0000100001 & 0020100100 & 0000000003 & 1101000020 & 0000000010 & 1221101 \\
\hline Unnamed taxon 7 & 0000100001 & 0020100100 & 0000000002 & 1101001020 & 0000000000 & 1221101 \\
\hline
\end{tabular}

